\title{
Hacker trial under way
}

\section{Washington}

THE trial of Robert Morris Jr, the college student charged with creating the 'Cornell virus' that struck thousands of US computers in 1988, began last week with only one thing clear: there seems little doubt that Morris is responsible for the rogue program.

What is far less certain is how current law should be interpreted in the case and what, if anything, a conviction will change.

Although most experts say there is compelling evidence that Morris wrote and released the computer program, many expressed surprise that the government had decided to prosecute him.

The law under which Morris is being prosecuted, the previously untested 1986 Computer Fraud and Abuse Act, is a graduate student at Cornell, in New York, but he first released the virus by sending it to a machine at Harvard University in Massachusetts. And among the computers subsequently infected by the virus were dozens of machines at government laboratories.

What remains to be seen is whether Morris can be said to have 'accessed' the infected computers himself. No doubt the virus did eventually into break and enter many machines, but by the time it began reproducing and transmitting itself across the country, Morris was just another bystander, helpless to stop it.

The very fact that prosecutors are forced to wrestle with such semantic questions is a reminder of the inadequacy of the current law, congressional aides say. They say that a more workable statute would focus on questions of criminal intent and malice, and define terms such as 'access' in such a way that direct agents such as virus are obviously included.

At least four bills to revamp the laws on computer use have been introduced in Congress, but even their supporters acknowledge that none of them would completely solve the problem. "It's a real challenge", says one Judiciary Committee staff member. "You have to anticipate the way people may be using computers in the future." Using specific terminology such as "virus" and "worm" is one pitfall that should be avoided. In 1986, when the current law was written, the very concept of a virus was known only to a small computing underground. And even today's hackers are hard pressed to guess what the computer crime vehicle of the future will be, or by what new name it will be called.

Morris has pleaded not guilty to the charges against him. His lawyers argue that he showed no malicious intent, and was trying only to demonstrate the weaknesses of the nationwide network. The virus did no permanent damage and only slowed the infected computers as it reproduced itself.

If Morris is found innocent of the charges, then the 1986 act has failed in its first test, and is badly in need of an overhaul, according to a Senate Judiciary Committee staff member. Such a decision would no doubt spur Congress to pass new legislation promptly. And even in the more likely case that he is found guilty, a congressional reappraisal of the whole issue of computer crime seems likely. But lawmakers are wary of overreacting by making the law so draconian that mere sloppy programming is against the law. "We have to use a scalpel, not a club", says one aide. "A bad bill can do more harm than a virus."

G. Chrlstopher Anderson

\section{Pollution clean up promised}

\section{Washington}

IN reaction to charges that US Antarctic bases are polluting the environment, the National Science Foundation (NSF) last week issued a pair of reports on how it could bring its polar activities into "full compliance with all applicable laws and foster environmentally responsible conduct by United States nationals in Antarctica".

NSF activities in Antarctica first came up public fire in 1988 when the Washingtonbased Environmental Defence Fund claimed that McMurdo Sound was more heavily polluted than the United States own coastal waters (see Nature 334, 643; 25 August 1988). McMurdo Station is the largest base in Antarctica with more than 1,000 scientists and maintenance crew in residence in the summer. The two other US bases are Amundsen-Scott at the South Pole and Palmer at Anvers Island off the Antarctic peninsula. NSF manages the entire US Antarctic programme and has admitted that mistakes in managing pollution were made in the past. Recently, several tens of thousands of gallons of fuel leaked onto the ice at McMurdo station.

The new plan, plus approval by Congress to spend $\$ 30$ million over the next four years, provides for the removal of all dangerous wastes from the bases, new equipment to clean up fuel spills, waste treatment plants at McMurdo and Palmer Stations, and a clean up of abandoned field camps. NSF will also develop a comprehensive programme to govern discharge of all pollutants.

Alun Anderson

\section{SPACE MANOEUVRES Dexterous performance by shuttle crew}

\section{Washington}

ASTRONAUTS on the US Space Shuttle Columbia successfully recovered the Long Duration Exposure Facility last Friday, manouvering the 11 ton orbiting laboratory into the shuttle cargo bay with the help of the Canadian-designed 50 foot manipulator arm.

The Long Duration Exposure facility has been orbiting the Earth for five and a half years. Once back on the ground, scientists will be able to assess experiments that include those designed to determine the long-term durability of structures placed in space (see Nature 343, 847; 21/28 December 1989). Photographs taken of the facility before it was placed in the cargo bay show that the metal foil covering some panels is damaged, peeled back or missing altogether. Columbia is expected to return to Earth on Friday this week. The ten-day flight, double the length of most shuttle missions, was partly designed to test future plans for month-long flights.

Alun Anderson out by Cornell University last year, Morris violated both parts of the statute. He was a 